Z Badań nad Książką i Księgozbiorami Historycznymi 2019. T. specjalny: Dla Niepodległej The Studies into the History of the Book and Book Collections 2019. Special issue: For an Independent Poland

\title{
Krajobraz w służbie patriotyzmu. Czasopisma krajoznawcze jako narzędzie wychowania patriotycznego w II Rzeczypospolitej ${ }^{1}$
}

\author{
Abstract \\ Landscape serving patriotism. Tourist and sightseeing \\ periodicals as tools for patriotic upbringing in the Second \\ Republic of Poland
}

The purpose of this paper is to present the conclusions from analyzing the content of the selected sightseeing periodicals issued in Polish in the Second Republic of Poland, focusing the research on: "Orli Lot", "Ziemia". When choosing the particular titles, not only the subject and language category were decisive, but also durability of particular tittles and their addressees. Therefore, we paid attention to periodicals published regularly and targeted to various reader groups, e.g. to adolescents. The research used methods proper to press studies and also was supported by geocriticism tools in order to reconstruct educational ideas propagated in the aforementioned periodicals. The ideas were supposed to, including but not limited to, create permanent system of moral concepts for the Poles, constituting grounds of the "new" citizen construct.

Key words: sightseeing press - Second Republic of Poland - „Ziemia” - „Orli Lot” - educational ideas - propaganda.

Słowa kluczowe: prasa krajoznawcza - II Rzeczypospolita - “Ziemia” - „Orli Lot” - idee wychowawcze - propaganda.

1 Artykuł zawiera odwołania do literatury opublikowanej do roku 2018.

„Z Badań nad Książką i Księgozbiorami Historycznymi” - Udział zagranicznych recenzentów w ocenie publikacji; Stworzenie anglojęzycznej wersji wydawniczej publikacji; Digitalizacja tomów archiwalnych rocznika w celu zapewnienia otwartego dostępu do nich przez Internet oraz wdrożenie i utrzymanie cyfrowej platformy redakcyjnej - zadanie finansowane w ramach umowy $\mathrm{nr}$ 653/P-DUN/2019 ze środków Ministra Nauki i Szkolnictwa Wyższego przeznaczonych na działalność upowszechniającą naukę. 
Dwudziestolecie międzywojenne w dziejach Polski zapisało się nie tylko jako czas odbudowy państwowości w wymiarze polityczno-ekonomicznym, ale także jako okres, zwłaszcza w historii myśli pedagogicznej, intensywnych poszukiwań najwłaściwszych metod służących ukształtowaniu obywatela nowego państwa, świadomego swojej tożsamości i obowiązków wobec ojczyzny. Analiza teorii pedagogiczno-wychowawczych obecnych w wypowiedziach nauczycieli, pedagogów i ideologów pozwoliła wyróżnić dwa główne stanowiska dotyczące podstaw pożądanego systemu aksjologicznego każdego obywatela, a szczególnie młodych ludzi w Rzeczypospolitej. Jedno eksponowało wartości chrześcijańskie, drugie ogólnohumanistyczne ${ }^{2}$. Dyskusje nad fundamentem aksjologicznym przedsięwzięć wychowawczych w dwudziestoleciu międzywojennym należy wpisać w szerszy wymiar sporów o charakterze ideologicznym, sporów uwarunkowanych światopoglądowo. W ideologii Narodowej Demokracji na przełomie XIX i XX w. doszło do scalenia romantycznych i pozytywistycznych wzorców wychowawczych z postulatami Ligi Narodowej kierowanej przez Romana Dmowskiego, czego efektem był wzorzec żołnierza-obywatela charakteryzującego się takimi cechami, jak: obowiązkowość, karność, zdyscyplinowanie, odpowiedzialność, podporządkowanie woli ogółu, gotowość służenia narodowi. Na gruncie ideologicznym odmienne stanowisko w kwestii wychowania zajął między innymi Jan Grabowski, którego postulaty stały się jednym z elementów polityki sanacyjnej ${ }^{3}$. Nadrzędną wartością w wychowaniu państwowym była Rzeczpospolita rozumiana jako własność ogółu obywateli, jako najwyższe dobro. Obywatel realizujący taką wizję państwa postępował zgodne z następującymi nakazami: realizowanie interesu grupowego nawet kosztem własnych potrzeb, bycie odpowiedzialnym, pracowitym, samodzielnym. Po śmierci Józefa Piłsudskiego obydwa wymienione dominujące modele wychowania - narodowy i państwowy - i tak już wcześniej mające wiele cech wspólnych, ewoluowały w kierunku jednego wzorca, stawiającego w centrum stosunek jednostki do państwa oraz narodu. Eksponowano w pożądanym modelu zachowań umiłowanie ojczyzny poprzez gotowość do poświęcenia się dla jej dobra oraz pracę dla podniesienia dobrobytu współobywateli ${ }^{4}$. Dwa środowiska socjalizujące, mające największy wpływ na kształtowanie osobowości - zwłaszcza młodych ludzi - czyli rodzina i szkoła, były wspomagane przez

2 Zob. Ł. Kabzińska, Idea wychowania moralno-społecznego w programach Międzynarodowych Kongresów Pedagogicznych okresu międzywojennego, „Warmińsko-Mazurski Kwartalnik Naukowy. Nauki Społeczne" 2013, nr 4, s. 39-66.

Zob. B. Jagiełło, Ksztaltowanie się koncepcji wychowania narodowego $i$ wychowania obywatelskiego w latach poprzedzajacych odzyskanie niepodlegtości (1900-1918), „Zeszyty Naukowe Akademii Muzycznej w Warszawie" 1983, nr 9, s. 52-67.

4 K. Jakubiak, Idea wychowania obywatelskiego w polskiej myśli pedagogicznej przełomu XIX i XX wieku oraz okresu II Rzeczypospolitej, „Chowanna” 1998, t. 2 (11), s. 68; M. Strzelecki, Wizje wychowania społecznego w polskiej myśli politycznej lat 1918-1939, Bydgoszcz 2008, s. 113-141. 
inne instytucje. Wśród nich można wymienić między innymi towarzystwa, organizacje, jak na przykład Polskie Towarzystwo Krajoznawcze (PTK), Polskie Towarzystwo Tatrzańskie (PTT), Związek Harcerstwa Polskiego (ZHP).

\section{Polskie Towarzystwo Krajoznawcze - idee, prasa}

Założyciele oraz członkowie PTK od początku istnienia tej instytucji, czyli od 1906 r., wskazywali na wartości wyższego rzędu kryjące się pod hasłami propagującymi wycieczki, poznawanie najbliższej okolicy oraz innych regionów. W okresie zaborów głównymi celami Towarzystwa były: integracja Polaków, podtrzymywanie w nich poczucia tożsamości narodowej, krzewienie poczucia dumy z bycia Polakiem, przygotowanie do stania się autentycznym gospodarzem ziemi, którą zamieszkiwali. Cele te oddawała dewiza PTK: „Przez poznanie kraju do jego umiłowania, przez umiłowanie do czynów ofiarnych"s. Wszystkie podejmowane zadania, np. gromadzenie informacji o zwyczajach i obrzędach danej lokalnej społeczności, rejestracja zabytków kultury materialnej, wytyczanie szlaków turystycznych, działania na rzecz ochrony przyrody wpisywały się w ideały wychowania korzeniami sięgające myśli Stanisława Konarskiego i założeń pedagogicznych KEN, z których wyrosły następnie XX-wieczne koncepcje wychowania narodowo-państwowego. Po odzyskaniu przez Polskę niepodległości Towarzystwo dopasowało organizację oraz funkcjonowanie do nowych uwarunkowań społeczno-politycznych, przy czym nadal dużą wagę przywiązywano do problematyki pedagogicznej. Świadczyła o tym działalność Aleksandra Patkowskiego, jednego z najaktywniejszych w latach międzywojennych animatorów krajoznawstwa ${ }^{6}$. Patkowski, współtwórca regionalizmu - programu stanowiącego element polityki państwowejuważał, że jego wprowadzenie w praktykę ułatwi unifikację ziem wchodzących

5 O historii i rozwoju krajoznawstwa w Polsce w latach międzywojennych jest już bogata literatura. Można wymienić, np. prace przygotowywane przez Komisję Historii i Tradycji Zarządu Głównego Polskiego Towarzystwa Krajoznawczo-Turystycznego i wydawane w ramach serii Studia i Materiały z Dziejów Krajoznawstwa Polskiego: Studia i materiały z dziejów krajoznawstwa polskiego. T. 1, wybór materiałów oraz układ tomu W. Skowron, J. Umiński, Warszawa 2006, t. 1; A. Czarnowski, Slynni krajoznawcy, Warszawa 2006, t. 2; Od PTK do PTTK, wybór materiałów oraz układ tomu W. Skowron, J. Umiński, red. E. Matusiak-Gordon, Warszawa 2009, t. 3; PTTK w roku sześćdziesięciolecia, wybór materiałów oraz układ tomu E. Wieczorek, J. Umiński, Warszawa 2010, t. 4; Kontynuacja pracy krajoznawczej jako wartość kulturotwórcza, wybór materiałów i układ tomu E. Wieczorek, Warszawa 2011, t. 5; Tożsamość Towarzystwa budowana przez pokolenia krajoznawców, wybór materiałów i układ tomu E. Wieczorek, Warszawa 2012, t. 6; Polsce stużyliśmy i stużyć będziemy, wybór materiałów i układ tomu W. Skowron, E. Wieczorek, Warszawa 2016, t. 10.

6 Na temat regionalizmu i A. Patkowskiego ukazało się wiele opracowań, m.in. E. Chudziński, Regionalizm. Idea - ludzie - instytucje, Warszawa 2013; A. Lubczyńska, Regionalizm kielecki w latach 1918-1939, Kielce 2008; Z. Wójcik, Aleksander Patkowski-pionier regionalizmu turystyczno-krajoznawczego w Polsce, Radom 2003; B. Wysocka, Regionalizm Wielkopolski w II Rzeczypospolitej 1919-1939, Poznań 1981. 
w skład nowej Rzeczypospolitej. Ponadto w ogłoszonym w 1924 r. programie (Idee przewodnie regionalizmu), wyznaczając główny cel, czyli „,szerzenie przywiązania do stron rodzinnych, pogłębianie czynnej roli obywatela do pracy zawodowo-społecznej"7, wytyczył drogę do jego osiągnięcia. Nauczycielom-regionalistom, którzy - jego zdaniem - byli w szczególny sposób predestynowani do realizowania programowych założeń, proponował metody i narzędzia pracy pozwalające w efekcie ukształtować nowego obywatela państwa. Ów nowy obywatel będzie, po pierwsze, umiał docenić wyjątkowość najbliższego mu regionu, a więc będzie dostrzegał piękno krajobrazu, unikatowość zwyczajów i obrzędów kultywowanych przez mieszkańców danego terenu. Po drugie, dzięki owej wrażliwości będzie rozbudzał w sobie przywiązanie do rodzinnej ziemi, co z kolei skłoni go do wytężonej pracy na rzecz dobra współmieszkańców ${ }^{8}$. Narzędziami ułatwiającymi realizację tak sformułowanych założeń regionalizmu były między innymi czasopisma9 ${ }^{9}$ PTK, jak i inne stowarzyszenia, powoływało do życia tytuły prasowe, które niejednokrotnie realizowały zadania wychodzące poza zakres programowy założycielskiego organu i włączały się na przykład w popularyzowanie państwowych ideologii wychowawczych.

Celem niniejszego tekstu jest analiza wybranych prasowych wypowiedzi poświęconych krajobrazowi jako tekstowi kultury ${ }^{10}$. Uwaga została skoncentrowana na zabiegach służących sfunkcjonalizowaniu tekstów, co miało wspomóc proces kształtowania i wychowania nowego obywatela w duchu ideałów narodowo-państwowych. Materiał egzemplifikacyjny zaczerpnięto z czasopism klasyfikowanych tematycznie do grupy pism krajoznawczo-turystycznych sygnowanych przez PTK i adresowanych do czytelnika dorosłego oraz młodzieżowego. Wybrano dwa czasopisma: „Ziemia” i „Orli Lot”" ${ }^{\text {. Analizę }}$

7 A. Patkowski, Idee przewodnie regionalizmu, „Przegląd Współczesny” 1924, t. 11, z. 30-32, s. $10-11$.

8 A. Patkowski, Projekt organizacji Uniwersytetu Powszechnego imienia Stanistawa Konarskiego dla nauczycielstwa szkót powszechnych i średnich oraz pracowników społecznych $i$ samorzadowych, „Oświata Pozaszkolna” 1923, nr 1, s. 46-47.

9 O roli czasopism dla młodych czytelników jako narzędzia w propagowaniu ideałów wychowawczych pisała m.in. Irena Socha w: Czasopisma dla młodzieży - literatura piękna - wychowanie literackie (1918-1939), Katowice 1990, Prace Naukowe Uniwersytetu Śląskiego w Katowicach, nr 1179, s. 153-155

10 Krajoznawcy okresu dwudziestolecia międzywojennego pisali o krajobrazie, mając na uwadze nie tylko naturalne ukształtowanie terenu, ale również ludność zamieszkującą dany region i efekty jej działalności.

11 Czasopisma te nie posiadają opracowań monograficznych. O ich historii i zawartości można znaleźć fragmenty w publikacjach poświęconych, np. Leopoldowi Węgrzynowiczowi: B. Boczukowa, Leopold Wegrzynowicz jako twórca koncepcji i redaktor pisma dla młodzieży „, Orli Lot”, „Ziemia" 1999, t. 54, s. 205-216; A. Czarnowski, Leopold Węgrzynowicz - organizator krajoznawstwa wśród młodzieży, Warszawa 1987. Opracowania doczekały się także wybrane zagadnienia poruszane na łamach tych pism, np.: J. Gajewski, ,Ziemia”, ,, Orli Lot” i góry, „Ziemia” 2016, t. 63, s. 175-208. 
przeprowadzono przy wykorzystaniu narzędzi prasoznawczych, jakich dostarcza metoda analizy zawartości prasy (przede wszystkim analizy treści), oraz pojęć geokrytyki wykorzystywanych we współczesnych badaniach regionalistycznych ${ }^{12}$.

Pierwszy numery „Ziemi” ukazał się z datą 1 I 1910 r., nosił podtytuł „Tygodnik Krajoznawczy Ilustrowany”. Inicjatorem pisma był Kazimierz Kulwieć - wiceprezes PTK. O zamiarach utworzenia periodyku zarząd PTK informował rok wcześniej w „Roczniku Polskiego Towarzystwa Krajoznawczego”:

Zawiązanie przed paru laty Polskiego Towarzystwa Krajoznawczego w Warszawie, zestrzelenie przez to w jedno ognisko rozbieżnie działających sił i dążeń pojedynczych jednostek było pierwszym krokiem na tym polu, krokiem, który wszelkie inne musiał nieodzownie poprzedzić. Teraz, jak mniemamy, nadszedł już czas, aby postawić krok drugi, aby przez założenie wydawnictwa, specjalnie krajoznawstwu poświęconego, wzmocnić niejako i rozszerzyć działalność Towarzystwa. Stajemy więc do pracy, ufni, że rola, którą orać idziemy, wyda plon bujny, że niebawem rąk ochoczych a zdatnych do pracy przybędzie, że nie padnie ziarno na opokę. Nie stoimy pod sztandarem żadnego stronnictwa, nie wygłaszamy żadnych bodajby najsłuszniejszych haseł politycznych czy społecznych, ograniczamy się z góry do skromnej, lecz niezbędnej naszym zdaniem pracy gromadzenia materiałów, z których każdemu wolno gmach własny wedle uznania budować. Jedynym przykazaniem naszym będzie: Poznaj swój kraj, abyś go tym goręcej miłował ${ }^{13}$.

Ostrożność władz Towarzystwa wybrzmiewająca w słowach deklarujących apolityczność przedsięwzięcia była, ze względu na ówczesne uwarunkowania historyczne, zrozumiała. Niemniej kończąca ten fragment apelatywna fraza wyraźnie wskazywała na idee patriotyczne przyświecające w pracy działaczom PTK. 27 II 1910 r. na walnym zebraniu członków Towarzystwa jednogłośnie podjęto uchwałę, na mocy której „Ziemia” stała się organem wydawniczym PTK $^{14}$. Oprócz Kulwiecia w skład pierwszej redakcji weszli: Stanisław Thugutt jako sekretarz i Mikołaj Wisznicki pełniący funkcję ilustratora i kierownika artystycznego. Do wybuchu I wojny światowej, mimo trudności przede wszystkim finansowych, wyszły 32 zeszyty. Kolejny, łączony numer (33-35) ukazał się po pięcioletniej przerwie z datą 8 VIII 1919 r. W ostatnim numerze z $1919 \mathrm{r}$. redakcja zapowiedziała zmianę rytmu ukazywania się pisma. Począwszy od roku 1920 „Ziemia”, miała być miesięcznikiem. Jeszcze dwukrotnie przed wybuchem II wojny światowej periodyk zmieniał częstotliwość ukazywania się. Od stycznia 1926 r. był dwutygodnikiem, a od 1932 r. ponownie pismo

12 E. Rybicka, Geopoetyka. Przestrzeń i miejsce we wspótczesnych teoriach i praktykach literackich, Kraków 2014, s. 92-11, 117-122; Z. Chojnowski, Literaturoznawstwo regionów (w poszukiwaniu skutecznych perspektyw badawczych), [w:] Nowy regionalizm w badaniach literackich. Badawczy rekonesans i zarys perspektyw, red. M. Mikołajczyk, E. Rybicka, Kraków 2012, s. 13-28.

13 Zapowiedź na rok 1910, „Rocznik Towarzystwa Krajoznawczego” 1909, R. 3, s. 5-6.

14 W.A. Wójcik, „Ziemia”. Od PTK do PTTK, „Ziemia” 2010, R. 61, s. 28. 
wydawano raz w miesiącu. Zmianom ulegał również skład redakcji, przy czym przez dłuższy czas, do 1926 r., osobą mającą znaczący wpływ na kształt pisma był jego pierwszy redaktor i wydawca K. Kulwieć. Później, do 1939 r., pismem kierowali kolejno: Aleksander Janowski, Regina Danysz-Fleszarowa, Konrad Górski, Jerzy Remer, ponownie A. Janowski i A. Patkowski ${ }^{15}$.

Współtwórcy PTK od początku istnienia organizacji dużą wagę przywiązywali do objęcia różnymi formami aktywności młodych ludzi. W celu upowszechnienia idei PTK, zwłaszcza wśród uczniów szkół gimnazjalnych, powoływano od 1918 r. młodzieżowe koła krajoznawcze ${ }^{16}$. Powstawały one przy każdym oddziale PTK, a na skutek inicjatywy członków oddziału krakowskiego, w 1918 r., założono Sekcję Krajoznawczą Młodzieży pod przewodnictwem Leopolda Węgrzynowicza ${ }^{17}$. Niejako naturalną konsekwencją tej decyzji, ale także dzięki determinacji samego Węgrzynowicza, utworzono czasopismo adresowane w pierwszej kolejności do członków tych kół, ale również do sympatyków, czy w ogóle do młodych ludzi. Pierwszy numer łączony (1-2) pod tytułem „Miesięcznik Krajoznawczy dla Młodzieży” ukazał się w 1920 r. (kwiecień-maj). W apelu skierowanym do czytelników nakreślono zadania, jakie pismo winno realizować:

Oddając pierwszy numer czasopisma, poświęconego krajoznawstwu, do rąk młodzieży, pragniemy rozdmuchać tę iskrę, która w młodocianym rozpala się wieku, iskrę miłości Ojczyzny, miłości wszystkiego co nasze, ziemi naszej, jej historii, zabytków i ludu polskiego. Poznać, aby ukochać - oto hasło nasze. Z tym hasłem idziemy do Was, Młodzieży Polska. Pragniemy, aby w czasie wolnym od nauki wszystkie ziemie polskie zaroiły się od gromadek młodych krajoznawców, by do nich przemówić mogły wszystkie góry i rzeki, wszystkie miasta, wsie, kościoły i zamki, chata polska i lud polski, by mogły przemówić swoją przeszłością, by mogły opowiadać im swe dole i niedole i ich życie obecne, żeby wszystko śpiewało im pieśń zwycięstwa i swobody, by odczuć i zrozumieć mogli, że ziemia ta i wszystko na niej to nasze, to polskie, zdobyte i wywalczone długowiekową pracą naszą i przodków naszych ${ }^{18}$.

W następnym numerze - trzecim - w winiecie figuruje już rozbudowany tytuł, czyli „Orli Lot. Miesięcznik Krajoznawczy dla Młodzieży”, który powstał z inspiracji Pieśnią o ziemi naszej Wincentego Pola. Redaktorem naczelnym miesięcznika, w numerach 1-8 z 1938 r., był L. Węgrzynowicz a następnie do wybuchu II wojny światowej Tadeusz Seweryn ${ }^{19}$.

15 O powojennych losach „Ziemi” zob. w: W.A. Wójcik, „Ziemia”..., s. 38-42.

16 Polskie Towarzystwo Krajoznawcze, Sprawozdanie za rok 1918, s. 8, [online] http://bstatuty. pttk.pl/Sprawozdanie_PTK_1918.pdf [dostęp 08.06.2018].

17 B. Boczukowa, Tradycje szkolnego ruchu krajoznawczo-turystycznego w Polsce, Siedlce 2003, s. 45-86; A. Czarnowski, Leopold Węgrzynowicz - organizator..., s. 23-35.

18 Do Młodzieży!, „Miesięcznik Krajoznawczy dla Młodzieży” 1920, nr 1-2, s. 1.

19 O powojennych losach pisma zob. w: A. Czarnowski, Leopold Wegrzynowicz..., s. 7-8. 


\section{Wypowiedzi o krajobrazie w służbie propagandy}

Na łamach „Ziemi” i „Orlego Lotu”, z racji profilu czasopism oraz wyznaczonych im celów, drukowano liczne teksty dotyczące walorów krajobrazowych Polski. Autorami tych wypowiedzi byli znawcy problematyki: podróżnicy, taternicy, wykładowcy botaniki, geografii, geologii, na uniwersytetach, m.in. w Krakowie, Lwowie, Wilnie. Wśród osób piszących do analizowanych periodyków znaleźli się na przykład: Jan Bystroń, Kazimierz Dobrowolski, Henryk Gąsiorowski, Zygmunt Gloger, Stanisława Niemcówna, Mieczysław Orłowicz, Ludomir Sawicki, Władysław Szafer. Artykuły zawierały zatem bogatą warstwę faktograficzną. Dzięki niej czytelnik mógł wzbogacać swoją wiedzę geograficzną, a także poznać specjalistyczne słownictwo z zakresu na przykład speleologii czy hydrologii. W tego typu tekstach nie brakowało jednocześnie fragmentów świadczących o przypisywaniu całej wypowiedzi nie tylko funkcji poznawczej, ale także perswazyjnej. Wyjątki te, będące opisami krajobrazu, zbudowano ze stereotypowych wyobrażeń z wykorzystaniem zabiegów mitologizujących przestrzeń.

Obrazowanie silnie sensualistyczne charakterystyczne było na przykład dla artykułów drukowanych w czasie, kiedy władze PTK dostrzegły osłabienie aktywności członków Towarzystwa, co tłumaczono „ogólnym zobojętnieniem w społeczeństwie”, „chorobą społeczną” objawiającą się brakiem inicjatyw i brakiem zainteresowania sprawami wykraczającymi poza działania zapewniające podstawy egzystencji. Osłabienie funkcjonowania PTK przed wybuchem I wojny światowej, o czym informowano w sprawozdaniach z poszczególnych oddziałów, zdaniem władz Towarzystwa stanowiło zagrożenie nie tylko dla ciągłości jego istnienia, ale również dla tożsamości narodowej Polaków. Pomysłem na aktywizację środowiska krajoznawców było zorganizowanie wystawy poświęconej polskiemu krajobrazowi ${ }^{20}$. Przedsięwzięciu temu, oprócz wyznaczenia celów stricte utylitarnych, a więc mobilizujących dotychczasowych członków PTK do uczestnictwa w tej akcji, nadano wymiar propagandowy. W zapowiedzi wydrukowanej na łamach „Ziemi” w trzecim numerze z $1911 \mathrm{r}$. akcentowano motywy natury ideowej mające zachęcić wszystkich czytelników pisma do aktywnego udziału w wystawie:

Zależność człowieka od przyrody kraju przezeń zamieszkiwanego, wykazana szczegółowo przez socjologów i biologów, przez historyków i geografów, stanowi najwdzięczniejszy bodaj temat wszelkich dociekań krajoznawczych. Przyroda ta stanowi to tło, tę glebę, na których człowiek wyrósł i ukształtował się tak w swej istocie fizycznej, jak i w strukturze duchowej $^{21}$.

20 W. Skowron, Krajobraz polski w centrum zainteresowania Polskiego Towarzystwa Krajoznawczego - wystawy fotograficzne, „Ziemia” 2010, t. 61, s. 219.

${ }_{21}$ Wystawa ,Krajobraz polski”, „Ziemia” 1911, t. 2, nr 23, s. 390. 
W tekście informującym o celach i organizcji wystawy pojawiły się zwroty nacechowane jednoznacznie pozytywnie, jak na przykład ,przyroda ojczysta”, „krajobraz polski”. Zabieg, jaki można zauważyć w ostatnim zdaniu wypowiedzi - zamianę przymiotnika „polski” na toponim „Polski” - wydobył ukryty, z obawy przed cenzurą, faktyczny sens ekspozycji. Chodziło zatem o przypomnienie narodowi jego praw do posiadania własnego terytorium, państwa, które już wcześniej istniało na mapach Europy. Redaktor „Ziemi”, otwierając wystawę, wygłosił mowę zawierającą stwierdzenia doskonale wpisujące się w ówczesne nowatorskie koncepcje wychowawcze. Kulwieć mówił o dobroczynnym wpływie obcowania człowieka z przyrodą, o wyjątkowych wrażeniach, jakie każdy przebywający w otoczeniu naturalnego krajobrazu doznawał. Prezes PTK akcentował zależności między środowiskiem naturalnym i zachowaniem człowieka. Był przekonany o tym, że kontakt z przyrodą, a w szczególności z przyrodą ojczystą, ,pobudza w duszy struny radosnego współdrgania"22. Przemowa K. Kulwiecia korelowała z ideologią skautowską, która wśród polskich pedagogów zdobywała coraz większą popularność. Organizowanie $\mathrm{z}$ dala od miejskich ośrodków obozów czy pieszych wędrówek to podstawowe formy pracy z młodzieżą propagowane przez Roberta Baden-Powella. Wielu krajoznawców oraz sympatyków tego ruchu, jak wspomniany już L. Węgrzynowicz, należało do skautingu. Węgrzynowicz wszedł na przykład w skład pierwszej Naczelnej Komendy Skautowej ${ }^{23}$. Pokłosiem wystawy Krajobraz Polski było między innymi wydanie katalogu oraz zredagowanie specjalnego numeru, był to dziewiąty numer „Ziemi” poświęcony zagadnieniom krajobrazu. Szczególne znaczenie dla rozumienia pojęcia „krajobraz narodowy" miał artykuł Jana Bułhaka - fotografa, teoretyka, który wywarł duży wpływ na rozwój fotografii w Polsce lat międzywojennych.

Dla Bułhaka fotografia była dziełem sztuki, a nie tylko mechanicznym zapisem danego obrazu. Efekt pracy fotografa-pejzażysty porównywał z obrazem malarza, w którym:

[...] nie tylko gra i mieni się barwa i światło, nie tylko dźwięczą wieloliczne tajne struny duszy ludzkiej, których zespół składa się na dzieło sztuki. Ponad to wszystko jest w krajobrazie coś jeszcze: jakaś niewyrażalna moc wewnętrzna, która czarem swym przepaja każdy szczegół, a całością uderza patrzącego prosto w serce. Jest nią - miłość. Ziemi rodzinnej miłość, poznanie, zżycie się i ukochanie tych pól i łąk, rozległych szumnych lasów i ruczajów świetlistych, na które codziennie patrzyły oczy dziecka, ucząc się wraz z pierwszym szczebiotem mowy ojczystej poznawać i wielbić wzorzyste zgłoski wielkiej księgi ojczystej przyrody ${ }^{24}$.

\footnotetext{
22 K. Kulwieć, Na otwarcie wystawy, „Ziemia” 1912, t. 3, nr 11, s. 176.

23 B. Boczukowa, Tradycje szkolnego ruchu..., s. 42.

24 J. Bułhak, Krajobraz i fotografia, „Ziemia” 1912, t. 3, nr 9, s. 137.
} 
Warunkiem osiągnięcia najwyższego artyzmu w obrazie czy fotografii przedstawiającej pejzaż było, zdaniem Bułhaka, zaistnienie, aby posłużyć się terminologią geokrytyki, owej przestrzennej mediacji ${ }^{25}$. Miłość bezwarunkowa, nieklasyfikująca elementów pejzażu na brzydkie i ładne, uczucie czyste i bezinteresowne pozwoli na uchwycenie ,istotnego rdzenia duszy własnej ziemi”"26. Bułhak przekonywał, że zastosowanie nowych rozwiązań technicznych w fotografii umożliwi autorom zdjęć zilustrowanie w pracach własnych uczuć:

[...] bierze fotograf rozbrat ze światem przedmiotów, traktowanym jako inwentarz ruchomości, wchodzi w świat przyrody żywej, zmiennej, wyrazistej, przenika w jej serce i stamtąd wydobywa i utrwala melodie i oddźwięki, rozbrzmiewające w jego własnej duszy. Na tej drodze zaczyna pojmować, iż nie uchwyci tajemnej, wewnętrznej mowy przyrody ten, kto bada tylko, co się wśród nich znajduje, zamiast słuchać, jak ona przemawia, zamiast patrzeć, jak się ona przedstawia w swoich wielkich żywiołowych rysach i liniach. Zaczyna pojmować, iż w niej, jak na całym obszarze odczuwania ludzkiego, nie ma rzeczy pięknych lub brzydkich, a są tylko - wyraziste, symbolicznie odpowiadające stanom zrosłej z nią ludzkiej duszy, gdy je cudnym rozświetli jaśnieniem: duszę - iskra mocy twórczej i serdecznego czucia, przyrodę - słońca promień radosny i złoty... Nie chodzi o to, co nam ukazuje artysta, tylko - jak to ukazuje, czy to czyni w sposób indywidualny, czy umie przekonać i wzruszyće ${ }^{27}$. Zacytowany wyjątek oddawał sens głównych założeń później popularyzowanej koncepcji fotografii ojczystej, której Bułhak był gorącym zwolennikiem, a która to miała akcentować narodowość i polskość ${ }^{28}$.

Jan Sunderland w 1932 r., próbując odpowiedzieć na pytanie: czy istnieją cechy narodowe w fotografice, przywoływał między innymi nazwisko Bułhaka, widząc w jego pracach analogie z malarstwem Leona Wyczółkowskiego, Artura Grottgera, u podstaw którego, jego zdaniem, leżała uczuciowość budowana z jednej strony przez liryzm, z drugiej - przez delikatny humor. Bułhaka uznawał też za przedstawiciela ojczystej fotografiki, najwartościowszej odmiany sztuki fotografii, gdyż wyrastała ona z fundamentów kultury danego narodu, czyli kultury ludowej, a jedną z jej emanacji był pejzaż ojczystej ziemi ${ }^{29}$. Artykuł Sunderlanda, podejmujący zagadnienie narodowości w sztuce, a dokładnie fotografiki, ukazał się w latach silnej władzy obozu piłsudczykowskiego. Rządy sanacji, zmieniając między innymi uwarunkowania prawne rozwoju prasy, wywarły wpływ na funkcjonowanie całego rynku czasopism ${ }^{30}$. Redakcje, zwłaszcza na początku lat 30 . XX w., musiały jednak liczyć się nie tylko z ewentualnymi

25 E. Rybicka, Geopoetyka. Przestrzeń i miejsce we wspótczesnych..., s. 249.

26 J. Bułhak, Krajobraz i fotografia..., s. 138.

27 Tamże, s. 142-143.

28 M. Szymanowicz, W poszukiwaniu ,,narodowości w fotografice”, „Artium Quaestiones” 2017, t. 28, s. 78-82; tenże, Topografia sukcesu, „Artium Quaestiones” 2006, t. 17, s. 83-99.

29 J. Sunderland, Cechy narodowe w fotografice, ,Ziemia”1932, t. 22, nr 10-12, s. 260.

30 J. Sobczak, Dzieje prawa prasowego na ziemiach polskich, Poznań 2009. 
restrykcjami prawnymi. Dotkliwe okazały się również problemy natury ekonomicznej dotykające w latach wielkiego kryzysu gospodarczego każdą gałąź gospodarki, każdy obszar życia społecznego i kulturalnego. „Ziemia” nie była wyjątkiem. Redaktorzy czasopisma w takiej sytuacji zaczęli poszukiwać innych oprócz prenumeraty źródeł dochodu. A. Janowskiemu w 1933 r. udało się uzyskać dotację z Funduszu Kultury Narodowej ${ }^{31}$, czego konsekwencją była konieczność dawania wyrazów poparcia dla idei państwowotwórczych rządzącego obozu ${ }^{32}$. Na pierwszej stronie trzeciego numeru z 1933 r. dedykowanego J. Piłsudskiemu z okazji jego imienin zamieszczono pod fotografią Marszałka wyjątki z jego wypowiedzi będące kwintesencją myśli o mocarstwowej Polsce $^{33}$. W numerze poprzednim (drugim z 1933 r.) składano życzenia, również imieninowe, Ignacemu Mościckiemu - „REPREZENTANTOWI NASZEGO MOCARSTWA", jak głosił podpis pod zdjęciem³. Warto dodać, że Fundusz Kultury Narodowej ustanowiony przez J. Piłsudskiego miał działać pod przewodnictwem prezydenta Rzeczypospolitej. Zatem dwa wspomniane numery można też potraktować jako dowód zapobiegliwość redakcji, starającej się nie stracić przychylności mecenasa. Wspomniany artykuł autorstwa Sunderlanda zatem jawi się nie tylko jako przejaw dyskusji o charakterze estetycznym, ale także zapowiedź wykorzystania obrazu, a dokładnie fotografii, do realizacji celów odmiennych od artystycznych. Mocarstwowe idee Piłsudskiego stały się kontekstem dla programu fotografii ojczystej, którego kodyfikatorem i gorącym propagatorem został Bułhak. Przekonanie o konieczności zaangażowania obrazu fotograficznego w sprawy narodowe, aby zdjęcie stanowiło nie tylko formę dokumentacji, ale wnosiło nowe treści w sferę poznawczą odbiorcy, aby łączyło wiedzę z estetyką, sprowadzało się do eksploatowania łatwo czytelnych wzorców. Bułhak, formułując założenia fotografii ojczystej, właściwie kontynuował swoje wcześniejsze poglądy na temat fotografii pejzażu. Przyjęcie pozaartystycznych zobowiązań tylko ugruntowało podstawowe wzorce wyrosłe z romantycznych wyobrażeń przestrzeni, między innymi z mitu kresowego. Dlatego fotografie, zwłaszcza pejzażu, ukazywały najczęściej krajobraz nizinny. Eksponowano elementy składające się na stereotypowe postrzeganie polskiego krajobrazu narodowego. W periodyku zamieszczano zdjęcia ze

${ }^{31}$ Fundusz Kultury Narodowej (1928-1937). Zarys działalności, Warszawa 1937, s. 34.

32 Świadczyła o tym zapowiedź kolejnego rocznika pisma, zamieszczona w ostatnim numerze z 1932 r. Prospekt uwzględniający nazwisko redaktora A. Janowskiego rozpoczynał się bowiem od deklaracji: „Semper Tibi, Polonia”. Temu hasłu: „Zawsze dla Ciebie, Polsko” służyć będzie ZIEMIA w roku nadchodzącym, jak służyła dotychczas prawie przez ćwierćwiecze. Celem Ziemi będzie oddanie swej służby IDEI MOCARSTWOWEJ POLSKI. Nasz front Mocarstwowej Myśli Polskiej ma wiele odcinków, a na jednym z nich ZIEMIA chce pełnić swój obowiązek żołnierski. Zob. Prospekt na rok 1933, „Ziemia” 1932, t. 22, nr 10-12, s. 288.

33 „Ziemia” 1933, t. 33, nr 3, s. 1.

34 Tamże, nr 2, s. 1. 
snopami zbóż lub stogami siana; z samotnymi sosnami, rozłożystym dębami; z brzozami rosnącymi wzdłuż polnych dróg; z wierzbami wyznaczającymi granice pól. Ważnymi wyznacznikami krajobrazu ojczystego były również dwory szlacheckie, kościoły, co odzwierciedlało bliski samemu Bułhakowi mit sarmacko-szlachecki ${ }^{35}$. Konsekwencją zaakceptowania propagandowej funkcji fotografii była konieczność dokumentowania rozwoju cywilizacyjnego młodej Rzeczypospolitej. Bułhak robił zdjęcia przemysłowego Śląska ${ }^{36}$, powstającego Centralnego Okręgu Przemysłowego czy budowanego portu w Gdyni. Fotografie obiektów przemysłowych odznaczały się charakterystyczną kompozycją świadczącą o umiejętnym połączeniu przez Bułhaka propagandowej wizji nowoczesnego państwa $z$ tradycją romantyczną. Fotograf architekturę przemysłową wkomponował w naturalny krajobraz, sugerując bezkonfliktową symbiozę tego, co przynależne naturze z efektami rozwoju cywilizacji ${ }^{37}$. Na łamach ,Ziemi" do ostatniego numeru w 1939 r. opublikowano 134 fotografie J. Bułhaka, z których 69 można zakwalifikować do zdjęć krajobrazu naturalnego. Głównymi elementami kompozycji tych zdjęć były drzewa - na przykład brzozy, dęby, jabłonie, jodły - polne drogi, czy jeziora, w tym zwłaszcza te znane z literatury romantycznej, jak Świteź. 11 zdjęć dokumentowało szlacheckie dworki i ruiny zamków, a na 22 ukazano kościoły lub obiekty sakralne ${ }^{38}$.

Krajoznawców dwudziestolecia międzywojennego, a szczególnie pedagogów zaangażowanych w propagowanie wśród młodzieży idei PTK, fascynowały góry postrzegane jako przestrzeń, która między innymi dzięki wyjątkowemu ukształtowaniu terenu w sposób szczególnie pozytywny miała oddziaływać na człowieka. Obcowanie z przyrodą, krajobrazem górskim w ich przekonaniu wzmacniało siły fizyczne, kształtowało charakter oraz uwrażliwiało estetycznie $^{39}$. Taki sposób postrzegania gór jako przestrzeni wypełniającej określone,

35 Motywy te były obecne $\mathrm{w}$ fotografiach wykonanych przez Bułhaka jeszcze zanim został kodyfikatorem programu Fotografii Ojczystej. Przykładem mogą być jego zdjęcia drzew, dróg polnych, dworków, kościołów, jeziora Świteź zamieszczone w numerze 10-12 „Ziemi” z 1925 r. „Ziemia” 1925, t. 10, nr 10-12.

36 M. Szymanowicz, Topografia sukcesu ..., s. 99-115. W „Ziemi” drukowano zdjęcia fotografów, którzy współpracowali z Bułhakiem i których prace pokazywano też np. na wystawie „Piękno Ziemi Śląskiej” zorganizowanej w 1938 r. przez Śląskie Towarzystwo Miłośników Fotografii oraz Związek Propagandy Turystyki Województwa Śląskiego. Byli to: Henryk Poddębski, Stefan Plater-Zyberk, właściciel agencji Photo-Plat.

37 M. Szymanowicz, Topografia sukcesu..., s. 103.

38 Obliczenia wykonano na podstawie analizy zawartości czasopisma „Ziemia” i informacji z: K. Polak, H. Polakowa, W.A. Wójcik, „Ziemia” 1910-1950. Bibliografia zawartości, Warszawa 1997, s. 285-289.

39 L. Węgrzynowicz, Organizacja ruchu krajoznawczego młodzieży szkolnej w Polsce, [b.m.] 1929, Pierwszy Ogólnopolski Kongres Krajoznawczy w Poznaniu, Sekcja V, [online] http://pbc.gda.pl/dlibra/ plain-content?id=5379 [dostęp 08.06.2018]; W. Firsoft, Taternictwo kształci charakter, „Turysta w Polsce” 1935, nr 6, s. 12; W. Krygowski, Obozy wędrowne i dalekobieżne wędrówki górskie, „Turysta w Polsce” 1935, nr 5, s. 3; F. Rapf, Wycieczki szkolne w Tatry, „Turysta w Polsce” 1935, nr 5, s. 4-5. 
narzucone funkcje, na przykład nakłanianie do aktywności, budzenie uczuć patriotycznych, popularyzowały artykuły, w których prezentowano obrazy krajobrazu górskiego nacechowane emocjonalnie. Teksty takie drukowano na przykład w czasie, kiedy ustalano ostateczny przebieg granic II Rzeczypospolitej i ważyły się losy Śląska, Spiszu i Orawy, Warmii i Mazur, ale także w dobie rządów obozu piłsudczykowskiego pod koniec lat 30. XX w.

Czwarty numer „Ziemi” z 1920 r. w całości poświęcono Spiszowi i Orawie. Redakcja w krótkiej notce informowała o konieczności, mimo zwiększenia objętości, pominięcia w tym zeszycie stałych rubryk, między innymi sprawozdań. Nie podano powodów tej decyzji, ale każdy czytelnik zapoznający się z zawartością pisma łatwo zorientował się że numer ten przygotowano z myślą o wykorzystaniu wszystkich materiałów w nim drukowanych w działalności propagandowej mającej na celu udowodnienie praw Polski do spornych terenów. Autorami poszczególnych tekstów byli między innymi członkowie PTK, PTT: wybitni historycy, jak Władysław Semkowicz, który już po ustaleniu południowej granicy założył Towarzystwo Kresów Południowych, żeby na tych terenach prowadziło działalność oświatowo-kulturalną; etnografowie, jak Juliusz Zborowski - dyrektor Muzeum Tatrzańskiego w Zakopanem; historycy kultury, jak Wacław Olszewicz, biorący aktywny udział w zakładaniu i prowadzeniu bibliotek oraz stowarzyszeń bibliotekarzy; pisarze, jak Mieczysław Świerz, Jan Wiktor; taternicy, jak Kazimierz Sosnowski czy już wymieniony Świerz. Autorzy doskonale potrafili włączyć w warstwę faktograficzną elementy wypowiedzi nadające ostatecznie całemu artykułowi ton propagandowy. J. Wiktor w emocjonalnym, otwierającym numer artykule pisał o podziwie dla ludności mieszkającej na Spiszu i Orawie, która mimo prześladowań nie zapomniała polskiej mowy i starych obyczajów. Posługując się figurą wroga, obrazował Czechów jako ciemiężców, szkalujących wszystko, co polskie i wynaradawiających górali spiskich i orawskich. Przeciwieństwem „czeskich żołdaków" ${ }^{40}$ byli owi górale - uczciwi, prostolinijni, którzy na wzór romantycznych męczenników pielęgnowali tradycje polskie. W zakończeniu artykułu $\mathrm{w}$ tonie apelatywnym, wzmacniając perswazję za pomocą słownictwa z obszaru sacrum, domagał się wzmożonej pracy, aby „zdobyć Spisz i Orawę [...], aby polska ziemia polską ostała. [...] A polską być musi" ${ }^{41}$. K. Sosnowski, koncentrując się na topografii i orografii Spiszu i Orawy, w czynnikach krajobrazowych, geologicznych, potamologicznych upatrywał argumentów na konieczność przyłączenia spornych terenów do Polski:

Nie poruszamy argumentów etnograficznych, politycznych, historycznych i ekonomicznych, które silniej jeszcze od geograficznych przemawiają za przynależnością Spiszu i Orawy

\footnotetext{
40 J. Wiktor, Poludniowe Kresy, „Ziemia” 1920, t. 6, nr 4, s. 99.

41 Tamże, s. 100.
} 
do Polski, nie poruszamy też węzłów geograficznych łączących okrąg Czadecki ze Śląskiem, które są prawie analogiczne z wyżej przytoczonymi [...]. Przyroda z w i ą z a $\nmid$ a Spisz, Orawę i Czadeckie z Polską ${ }^{42}$.

Kolejne artykuły wypełniające łamy tego numeru „Ziemi” dostarczały wielu informacji o folklorze, języku, religijnej pieśni mieszkańców Spiszu i Orawy, o architekturze, zabytkach sztuki sakralnej oraz ludowej, przy czym interpretacja tego materiału jednoznacznie utwierdzała czytelników w przekonaniu o polskości Orawian i Spiszaków i tym samym o potrzebie włączenia ziem przez nich zamieszkałych do Rzeczypospolitej.

Z podobnymi w tonie tekstami, podporządkowanymi celom perswazyjnym, mieli do czynienia czytelnicy „Orlego Lotu”. Wynikało to również z faktu, że oba tytuły miały tego samego wydawcę i oba realizowały cele PTK. Dodatkowo wielu autorów współpracujących z ,Ziemią” równocześnie drukowało swoje artykuły w „Orlim Locie”. W trzecim numerze pisma z 1920 r. K. Sosnowski opublikował artykuł pod tytułem Krajoznawczy rzut oka na Spisz i Orawę, rozpoczynając go od fragmentu jednoznacznie waloryzującego opisywaną przestrzeń:

Pozyskanie dla Polski Spiszu i Orawy miałoby dla naszego krajoznawstwa i turystyki nieocenione znaczenie, mimo to, iż chodzi o obszary stosunkowo niewielkie. Znaczenie to tkwi w tym, że są to kraje wybitnie górskie z niewysłowionej piękności krajobrazem, obfitujące w prawdziwe cuda przyrody. Polska jest krajem nizinnym, posiadającym gór wyższych nader mało, a mianowicie posiada tylko łańcuch Beskidu ze szczytami średniej wysokości i mały skrawek Tatr, należących do typu wysokogórskiego, toteż pozyskanie nowych obszarów górskich jest dla niej z wielu względów prawdziwą koniecznością ${ }^{43}$.

Podobnie w tonie apelatywnym, opatrując praktycznie każdy toponim przymiotnikiem ,,polski”, o Orawie i Spiszu pisał W. Semkowicz:

Wydarto nam w pierwszym rozbiorze Polski piękny Spisz - wyłupano w koronie Piastów i Jagiellonów najcenniejszy kamień, własnymi rękami naszymi wyrzezany. A dziś, gdy Sprawiedliwość Boża zwraca Narodowi Polskiemu tę koronę, czyż mamy ów kamień drogocenny pozostawić w ręku zaborczego sąsiada, czy nim będzie Czech czy Madziar? Czyż możemy wyrzec się tej odwiecznie polskiej, przecudnej podtatrzańskiej ziemicy, w którą tyle krwi, tyle znoju, tyle pierwiastków polskiego ducha i polskiej kultury wsiąknęło? Przenigdy! Spisz wróci - musi wrócić do Polski i za nic nie oddamy tego, co sama natura wstęgą Popradu związała z lechickich Wisły zlewiskiem ${ }^{44}$.

Relacja z wyprawy do Doliny Białej Wody pióra K. Dobrowolskiego, etnologa z Uniwersytetu Jagiellońskiego, to doskonała ilustracja topografii emotywnej realizującej romantyczny wzorzec kategorii wzniosłości. Dolina Białej Wody, zgodnie z konwencją romantyczną, ukazana została jako dzika kraina

${ }^{42}$ K. Sosnowski, Nieco z geografii i turystyki Spisza i Orawy, „Ziemia” 1920, t. 6, nr 4, s. $102-$ 103.

43 K. Sosnowski, Krajoznawczy rzut oka na Spisz i Orawe, „Orli Lot” 1920, t. 1, nr 3, s. 20.

44 W. Semkowicz, Śladami kultury polskiej na Spiszu, „Orli Lot” 1920, t. 1, nr 3, s. 26. 
i „porywająca niewypowiedzianym urokiem wąwozów górskich”45. Punktem wyjścia do budowania sensualistycznego obrazowania przestrzeni, ponieważ eksponowano przede wszystkim emocje wywołane widokiem konkretnego krajobrazu, były doświadczenie wzrokowe, w których ważną rolę odgrywał kolor:

Od wschodu wionie poblask łuny. Nagle gorące promienie słońca starly z oblicza niebios blady róż. Świt w pełni. Głownie słoneczne płyną potokami od Spiskiej Magury na jaworzyńskiej polany lśniące krasą opalowych rós. Przed nami Murań z wierchami tkanymi szlakiem ogniowym, Murań skalny olbrzym. Nagie jego ściany jakby zalane morzem liliowych kosaćców - niżej ciemne plamy kosówki, a u stoków płaty smreków z wyzłacanymi czubami ${ }^{46}$.

Krajobraz wizualny uzupełniany był zapisem elementów tworzących krajobraz dźwiękowy. Warto tutaj podkreślić że już romantycy (Antoni Edward Odyniec, Ludwik Zejszner, Maria Steczkowska) zwracali uwagę na doznania akustyczne $\mathrm{w}$ górach ${ }^{47}$. W tekstach $\mathrm{z}$ dwudziestolecia międzywojennego rejestrowano huk wodospadów, szum wiatru, ale też przejmującą ciszę. Zapis sensualistycznego krajobrazu skonstruowany z metaforycznych, rozbudowanych epitetów, symboliki akwatycznej, słownictwa batalistycznego, środków animizujących niejednokrotnie służył sakralizowaniu danej przestrzeni, co ostatecznie wzmacniało sfunkcjonalizowanie całej wypowiedzi ${ }^{48}$. K. Dobrowolski kończył opis krajobrazu Doliny Białej Wody konstatacją utrwalającą w wyobraźni czytelników konkretne wyobrażenie określonej przestrzeni, ale przede wszystkim w wymiarze emotywnym:

Niezapomniane widoki, niewygasłe nigdy w pamięci przeżycia... Tu w zetknięciu ze światem Tatr doznają ukojenia nasze tęsknoty za czymś nieznanym, pięknym, za jasnym jutrem, tęsknoty, co jak śnieżyczki pod bielą śniegu, kryją się w głębinach naszego serca. Tu czar gór w duszy płynący podnosi skrzydła do górnych lotów i zamierzeń! ${ }^{49}$.

W 1938 r. wkroczenie wojsk polskich na teren Zaolzia i aneksja tych obszarów spotkała się z entuzjastycznym komentarzem redakcji „Ziemi”. W dziesiątym numerze na drugiej stronie pod wydrukowanym wytłuszczonymi wersalikami tytułem $W$ dnie powrotu Ziemi Piastowskiej na Ojczyzny tono zamieszczono podziękowania zarządu PTK kierowane do prezydenta Rzeczypospolitej I. Mościckiego, marszałka Edwarda Rydza-Śmigłego, premiera gen. Felicjana Sławoja-Składkowskiego oraz ministra spraw zagranicznych Józefa Becka. W owych listach pojawiło się określenie „prastara dzielnica Polski”, które w odniesieniu do Zaolzia powtarzane było w innych artykułach

45 K. Dobrowolski, Ze wspomnień jaworzyńskich, „Orli Lot” 1922, t. 3, nr 2, s. 18.

46 Tamże.

47 E. Słoka, Romantyczna dolina. Czesść II, „Góry - Literatura - Kultura” 2001, t. 4, s. 115-116.

48 Por. J. Kolbuszewski, Tatry romantyczne, [w:] tenże, Tatry. Literacka tradycja motywu gór, Kraków 1995, s. 27-53.

49 K. Dobrowolski, Ze wspomnień..., s. 18. 
drukowanych w kolejnych numerach pisma ${ }^{50}$. Numer 12 . z tego samego roku w całości poświęcony Karpatom otwierała ilustracja przedstawiająca obraz Przewodnik i turyści w Tatrach Walerego Eljasza-Radzikowskiego ${ }^{51}$. Nieprzypadkowo wybrano akurat ten obraz, ponieważ zgodnie z powszechną interpretacją Eljasz-Radzikowski najprawdopodobniej przedstawił na nim szlak na Polski Grzebień i nazwa właśnie tej przełęczy została umieszczona pod ryciną w „Ziemi”. Dla redakcji krajoznawczego periodyku istotny był kontekst historyczny dla wydarzenia z 1938 r. Przywołano bowiem osobę Eljasza-Radzikowskiego, malarza, fotografa, miłośnika Tatr, autora pierwszych przewodników, piszącego w 1901 r. o „wydzieraniu” Polakom przez Węgrów Tatr, które „pierwotnie do Polski należały całe” i „do dziś dnia lud tamtejszy wedle tradycji żywo jeszcze przechowywanej wskazuje koło Preszowa dawne granice Polski" ${ }^{2}$. Przyłączenie Zaolzia pod koniec lat 30. XX w. uznano zatem za akt dziejowej sprawiedliwości. Jerzy Młodziejowski w artykule pod tytułem Odzyskane Tatry, otwierającym 12. numer „Ziemi” w pierwszym zdaniu podkreślił fakt powrotu do Polski części Wysokich Tatr, dając tym samym do zrozumienia, że dotychczasowa granica przebiegająca przez ten obszar była tymczasowa, wyznaczona arbitralnie z pominięciem w tej kwestii głosu Rzeczypospolitej. Autor przywołując nazwy topograficzne szczytów, dolin, przełęczy, osad, nie krył emocjonalnego stosunku do opisywanej przestrzeni. Epitety porównania, jakich używał, przypominały te z wypowiedzi drukowanych w latach 20., kiedy ważyły się losy Śląska, Spiszu i Orawy. Zauważyć można wysoką frekwencję towarzyszącego toponimom przymiotnika polski, co miało za zadanie dodatkowo uargumentować słuszność decyzji rządu polskiego o zajęciu Zaolzia:

Obszar nowo odzyskanych Tatr zasługuje na baczną uwagę: kryją się w nim niezwykłej piękności krajobrazy, cudowna szata roślinna, słynny świat zwierzęcy Jaworzyny, nieprzebrane skarby turystycznych doznań, a nade wszystko świadomość, że oto chodzić będziemy znowu na «polski» Polski Grzebień i że Biała Woda znowu szumieć będzie «po polsku» [...]; tłumy naszych wędrowców odkrywać będą nowe polskie Tatry Jaworznickie ${ }^{53}$.

W artykule Młodziejowski przywołał nazwiska polskich badaczy, między innymi Adama Gadomskiego, Bronisława Halickiego, Zbigniewa Korosadowicza, Eugeniusza Romera, L. Sawickiego, Józefa Szaflarskiego, dzięki którym powstały prace z zakresu botaniki, geologii, hydrologii obszaru północnych stoków Wysokich Tatr, co również świadczyło o pamięci i stałym

\footnotetext{
50 „Ziemia” 1938, t. 28, nr 10, s. 212.

Tamże, nr 12, s. 287.

52 W. Eljasz-Radzikowski, Spór o granicę w Tatrach, Kraków 1901, s. 3. Broszura jest odbitką artykułu, który autor anonimowo wydrukował w numerze 29 „Przeglądu Zakopiańskiego” z 1901 r., s. $265-266$.

53 J. Młodziejowski, Odzyskane Tatry, „Ziemia” 1938, t. 28, nr 12, s. 288-289.
} 
zainteresowaniu Polaków tymi terenami, chociaż znalazły się poza granicą ojczyzny. Artykuł kończył mocny akcent - zdanie w formie imperatywu: „Nikt doń do [Jaworzyny KT] prócz Polaków nie ma praw"54.

Redaktorzy „Ziemi” i „Orlego Lotu” perswazyjność tekstów eksponujących motyw górskiego krajobrazu wzmacniali poprzez dołączanie materiału ikonicznego w formie wykresów, szkiców, map i zdjęćs ${ }^{55}$. Często były to fotografie szczytów, na przykład Babiej Góry, Zamarłej Turni, a ich obecność miała na celu wzmocnienie przekazu słownego, zwizualizowanie obiektu uczuć. Pejzaż bowiem kreślony za pośrednictwem słowa był, co warto jeszcze raz podkreślić, pejzażem emotywnym. Fotografie szczytów, ale też dolin otoczonych skalnymi ścianami, ilustrowały monumentalizm gór i tym samym intensyfikowały siłę przekazu danej wypowiedzi, w tym jej funkcję propagandową.

\section{Zakończenie}

Analiza zawartości wybranych czasopism krajoznawczo-turystycznych potwierdziła słuszność ustaleń prasoznawców, zajmujących się historią mediów okresu dwudziestolecia międzywojennego, na temat oblicza prasy. Jak pisał Wiesław Władyka, czasopisma były ,[...] zwierciadłem jej [Rzeczypospolitej KT] kłopotów ekonomicznych i społecznych, perturbacji politycznych" ${ }^{56}$. Biorąc pod uwagę cele, wymienione na początku artykułu, można uznać, że zaprezentowany materiał zaczerpnięty z „Ziemi” i „Orlego Lotu” stanowi ilustrację syntezy idei regionalizmu i założeń powojennego krajoznawstwa, do czego w latach 30. XX w. włączono założenia programu fotografii ojczystej i piłsudczykowskie idee wychowania narodowo-patriotycznego. Ostatecznym efektem lektury tych wypowiedzi miał być nowy obywatel na miarę nowego, silnego państwa.

\section{Bibliografia}

Boczukowa B., Leopold Węrzynowicz jako twórca koncepcji i redaktor pisma dla mtodzieży „, Orli Lot”, ,Ziemia” 1999, t 54, s. 205-216.

Boczukowa B., Tradycje szkolnego ruchu krajoznawczo-turystycznego w Polsce, Siedlce 2003.

\footnotetext{
54 Tamże, s. 299.

55 Jednym $z$ najbardziej znanych fotografów Zakopanego i Tatr w dwudziestoleciu międzywojennym był Marian Antoni Wieczorek, polemizujący z poglądami Bułhaka na temat programu Ojczystej Fotografii. Jego zdjęcia reprezentowały odmienny nurt (idealizujący) fotografii podporządkowanej celom pozaartystycznym. M. Szymanowicz, Topografia sukcesu..., s. 105-107;

56 W. Władyka, Prasa Drugiej Rzeczypospolitej, [w:] J. Łojek, J. Myśliński, W. Władyka, Dzieje prasy polskiej, Warszawa 1988, s. 92.
} 
Bułhak J., Krajobraz i fotografia, „Ziemia” 1912, t. 3, nr 9, s. 136-143.

Chudziński E., Regionalizm. Idea - ludzie - instytucje, Warszawa 2013.

Chojnowski Z., Literaturoznawstwo regionów (w poszukiwaniu skutecznych perspektyw badawczych), [w:] Nowy regionalizm w badaniach literackich. Badawczy rekonesans i zarys perspektyw, red. M. Mikołajczyk, E. Rybicka, Kraków 2012, s. 13-28.

Czarnowski A., Leopold Węrzynowicz - organizator krajoznawstwa wśród młodzieży, Warszawa 1987.

Czarnowski A., Stynni krajoznawcy, Warszawa 2006, Studia i Materiały z Dziejów Krajoznawstwa Polskiego, t. 2.

Do Młodzieży!, „Miesięcznik Krajoznawczy dla Młodzieży” 1920, nr 1-2, s. 1-2.

Dobrowolski K., Ze wspomnień jaworzyńskich, „Orli Lot” 1922, t. 3, nr 2, s. 18-19.

Eljasz-Radzikowski W., Spór o granicę w Tatrach, Kraków 1901.

Firsoft W., Taternictwo kształci charakter, „Turysta w Polsce” 1935, nr 6, s. 12.

Fundusz Kultury Narodowej (1928-1937). Zarys działalności, Warszawa 1937.

Gajewski J., ,Ziemia”, ,, Orli Lot” i góry, „Ziemia” 2016, t. 63, s. 175-208.

Jagiełło B., Kształtowanie się koncepcji wychowania narodowego i wychowania obywatelskiego w latach poprzedzających odzyskanie niepodległości (1900-1918), „Zeszyty Naukowe Akademii Muzycznej w Warszawie" 1983, nr 9, s. 52-67.

Jakubiak K., Idea wychowania obywatelskiego w polskiej myśli pedagogicznej przetomu XIX i XX wieku oraz okresu II Rzeczypospolitej, „Chowanna” 1998 , t. 2 (11), s. 62-71.

Kabzińska Ł., Idea wychowania moralno-społecznego w programach Międzynarodowych Kongresów Pedagogicznych okresu międzywojennego, „Warmińsko-Mazurski Kwartalnik Naukowy. Nauki Społeczne" 2013, nr 4, s. 39-66.

Kolbuszewski J., Tatry. Literacka tradycja motywu gór, Kraków 1995.

Kontynuacja pracy krajoznawczej jako wartość kulturotwórcza, wybór materiałów i układ tomu E. Wieczorek, Warszawa 2011, Studia i Materiały z Dziejów Krajoznawstwa Polskiego, t. 5.

Krygowski W., Obozy wędrowne i dalekobieżne wędrówki górskie, „Turysta w Polsce” 1935, nr 5, s. 3.

Kulwieć K., Na otwarcie wystawy, „Ziemia” 1912, t. 3, nr 11, s. 175-176.

Lubczyńska A., Regionalizm kielecki w latach 1918-1939, Kielce 2008.

Łojek J., Myśliński J., Władyka W., Dzieje prasy polskiej, Warszawa 1988.

Młodziejowski J., Odzyskane Tatry, „Ziemia”1938, r. 28, nr 12, s. 288-294.

Nowy regionalizm $w$ badaniach literackich. Badawczy rekonesans i zarys perspektyw, red. M. Mikołajczyk, E. Rybicka, Kraków 2012.

Od PTK do PTTK, wybór materiałów oraz układ tomu W. Skowron, J. Umiński, red. E. Matusiak-Gordon, Warszawa 2009, Studia i Materiały z Dziejów Krajoznawstwa Polskiego, t. 3.

Patkowski A., Idee przewodnie regionalizmu, „Przegląd Współczesny” 1924, t. 11, z. 30 32, s. 3-14. 
Polak K., H. Polakowa, W.A. Wójcik, „Ziemia” 1910-1950. Bibliografia zawartości, Warszawa 1997.

Polskie Towarzystwo Krajoznawcze, Sprawozdanie za rok 1918, s. 8, [online] http://bstatuty.pttk.pl/Sprawozdanie_PTK_1918.pdf [dostęp 08.06.2018].

Polsce stużyliśmy i służyć będziemy, wybór materiałów i układ tomu W. Skowron, E. Wieczorek, Warszawa 2016, Studia i Materiały z Dziejów Krajoznawstwa Polskiego, t. 10. PTTK $w$ roku sześćdziesięciolecia, wybór materiałów oraz układ tomu E. Wieczorek, J. Umiński, Warszawa 2010, Studia i Materiały z Dziejów Krajoznawstwa Polskiego, t. 4.

Studia i materiały z dziejów krajoznawstwa polskiego, wybór materiałów oraz układ tomu W. Skowron, J. Umiński, Warszawa 2006, t. 1.

Rapf F., Wycieczki szkolne w Tatry, „Turysta w Polsce” 1935, nr 5, s. 4-5.

Rybicka E., Geopoetyka. Przestrzeń i miejsce we wspótczesnych teoriach i praktykach literackich, Kraków 2014.

Semkowicz W., Śladami kultury polskiej na Spiszu, „Orli Lot” 1920, t. 1, nr 3, s. 24-26.

Skowron W., Krajobraz polski w centrum zainteresowania Polskiego Towarzystwa Krajoznawczego - wystawy fotograficzne, „Ziemia” 1999, 2010, t. 61, s. 217-230.

Słoka E., Romantyczna dolina. Część II, „Góry - Literatura - Kultura” 2001, t. 4, s. 115 116.

Sobczak J., Dzieje prawa prasowego na ziemiach polskich, Poznań 2009.

Socha I., Czasopisma dla młodzieży - literatura piękna - wychowanie literackie (19181939), Katowice 1990, Prace Naukowe Uniwersytetu Śląskiego w Katowicach, nr 1179.

Sosnowski K., Krajoznawczy rzut oka na Spisz i Orawę, „Orli Lot” 1920, t. 1, nr 3, s. 20-24.

Sosnowski K., Nieco z geografii i turystyki Spisza i Orawy, „Ziemia” 1920, t. 6, nr 4, s. 100-107.

Sunderland J., Cechy narodowe w fotografice, „Ziemia” 1932, t. 22, nr 10-12, s. 258-263.

Szymanowicz M., Topografia sukcesu, „Artium Quaestiones” 2006, t. 17, s. 75-128.

Szymanowicz M., W poszukiwaniu ,,narodowości w fotografice”, „Artium Quaestiones” 2017 , t. 28 , s. 65-86.

Tożsamość Towarzystwa budowana przez pokolenia krajoznawców, wybór materiałów i układ tomu E. Wieczorek, Warszawa 2012, Studia i Materiały z Dziejów Krajoznawstwa Polskiego, t. 6.

Węgrzynowicz L., Organizacja ruchu krajoznawczego młodzieży szkolnej w Polsce, [b.m.] 1929, Pierwszy Ogólnopolski Kongres Krajoznawczy w Poznaniu, Sekcja V, [online] http://pbc.gda.pl/dlibra/plain-content?id=5379 [dostęp 08.06.2018].

Wiktor J., Poludniowe Kresy, „Ziemia” 1920, t. 6, nr 4, s. 98-100.

Wójcik W. A., ,Ziemia”. Od PTK do PTTK, „Ziemia” 2010, s. 25-42.

Wójcik Z., Aleksander Patkowski - pionier regionalizmu turystyczno-krajoznawczego w Polsce, Radom 2003. 
Wysocka B., Regionalizm Wielkopolski w II Rzeczypospolitej 1919-1939, Poznań 1981. Wystawa „Krajobraz polski”, „Ziemia” 1911, t. 2, nr 23, s. 390-391.

Zapowiedź na rok 1910, „Rocznik Towarzystwa Krajoznawczego” 1909, t. 3, s. 5-8. 
